\title{
Chemical, physical and thermal characterization of wood pellets from different compositions
}

\author{
Bruno Silva Camargo' \\ Aldo Braghni Junior" \\ Sâmique Kyene de Carvalho Araújo Camargo'"I \\ José Claúdio Caraschilv
}

\begin{abstract}
Pellets are characterized by renewable biomass and may be an option for replacing fossil fuels. The objective of this paper is to analyze and compare a set of pellets of different compositions, based on their physical, chemical and thermal characteristics for energy purposes, comparing them against international standards. To this end, the international standards SS187120 (Swedish), ONORM M7135 (Austrian), DIN 51731 (German) and the official standards recommended by the Pellets Fuel Institute (PFI) (United States) were used as reference for the parameters analyzed. Three types of pellets were analyzed: Pinus ssp. with $15 \%$ in mass of charcoal fines (P1), Pinus ssp. (P2) and Eucalyptus ssp. (P3). The analyses carried out indicated that the P1 pellets had the greatest higher heating value $(20.52 \mathrm{MJ} . \mathrm{kg}-1)$. With regard to moisture content, mechanical durability and bulk density, all pellets achieved the quality parameters. Regarding the gaseous emissions of carbon monoxide (CO), some of the pellets presented values higher than the CONAMA standard. As for NOX emissions, they presented values below the standard and there were no emissions of SO2. Thus, it can be observed that the different types of pellets analyzed had a high energy potential according to the Austrian standard ONORM M7135.
\end{abstract}

Keywords: Pellets; Pinus ssp; Charcoal fines; Heating power; Gaseous emissions

\section{Resumo}

Os pellets são caracterizados como biomassa renovável e podem ser uma opção para substituir combustíveis fósseis. O objetivo deste artigo é analisar e comparar pellets provenientes de diferentes composições, em relação as suas características físicas, químicas e térmicas para fins energéticos, comparandoos com os padrões internacionais. Para isso, foram utilizadas como referência os parâmetros internacionais SS187120 (sueco), ONORM M7135 (Austríaca), DIN 51731 (Alemã) e os padrões oficiais recomendados pelo Pellets Fuel Institute (PFI) (Estados Unidos). Foram analisados três tipos de pellets: Pinus ssp. com 15\% em massa de finos de carvão vegetal (P1), Pinus ssp. (P2) e Eucalyptus ssp. (P3) As análises realizadas indicaram que os pellets P1 apresentaram maior poder calorífico superior (20,52 MJ.kg-1). Com relação ao teor de umidade, durabilidade mecânica e densidade a granel, todos os pellets atingiram os parâmetros de qualidade.

\footnotetext{
I PhD Student, Mechanical Engineering, Paulista State University - UNESP, Itapeva-SP, Brazil, bs.camargo@hotmail.com.

"PhD, Production Engineering, Federal Technological University of Paraná - UTFPR, Ponta Grossa-PR, Brazil.

IIIPhD Student, Mechanical Engineering, Paulista State University - UNESP, Itapeva-SP, Brazil

${ }^{I V} \mathrm{PhD}$, Chemical Engineering, Paulista State University - UNESP, Itapeva-SP, Brazil.
} 
Em relação às emissões gasosas de monóxido de carbono (CO), parte dos pellets apresentaram valores superiores a norma CONAMA. Quanto às emissões de NOX, estas apresentaram valores abaixo do estabelecido pela norma e não houve emissões de SO2. Assim, pode-se observar que os diferentes tipos de pellets analisados apresentaram alto potencial energético, conforme a norma austríaca ONORM M7135.Palavraschave: Pellets. Pinus ssp. Charcoal fines. Heating power. Gaseous emissions.

Palavras-chave: Pellets; Pinus ssp; Finos de carvão vegetal; Potencial energético; Emissões gasosas 


\section{Introduction}

Biomass is a source of clean and renewable energy and it is one of the main alternatives for replacing non-renewable energy sources, such as charcoal and oil, assisting to reduce the dependence on fossil fuels (ZOU et. al., 2016). Among the most used biomass energy sources worldwide are pellets (TOSCANO et al., 2013; ARRANZ et al., 2015), which are a source of "green" fuel, seeking to reduce carbon emissions. Pellets present superior characteristics than other biomass products, e.g. high density, high stability and low moisture content (MC) (DENG; ALZAHRANI; BRADLEY, 2019). Such high density, results in lower transportation costs and higher efficiency in energy conversion, thus, showing adequate properties for residential (domestic heating) and industrial (replacement of charcoal) use.

The raw material for the production of pellets comes from plant biomass, comprising: sawdust, wood bark and pulp, and other by-products from logging industries, also agricultural raw materials, such as lignocellulosic straws of grasses of the Miscanthus genus (LEHMANN et al., 2012), as well as the sugarcane bagasse and bamboo (MANI et al., 2006). If compared to other solid biofuels, pellets have high energy density, which levels them with fossil fuels in this regard. According to, pellets have a moisture content of approximately $8 \%$ and bulk density higher than $600 \mathrm{~kg} / \mathrm{m}^{3}$. This makes the advantageous over wood chips, since the moisture content and energy density of wood chips vary from 40 to $50 \%$ and 220 to $250 \mathrm{~kg} / \mathrm{m} 3$, respectively.

Wood pellets are currently one of the largest solid biomass fuels marketed internationally and, as capacity and production increase worldwide, international market is likely to increase further (SIKKEMA, 2011). Currently, the European Union is the world leader in the wood pellet market and produces approximately 50\% of the world's wood pellets, while consuming about $67 \%$ of the same demand. Other parts of the world also have been growing in this sector, such as the United States and Canada (FAO STAT, 2017).

In this context, Brazil stands out as the largest producer of pellets in Latin America, totaling 470,900 tons of pellets in 2017 (FAO STAT, 2017). However, in Brazil, there is no standardization on the characterization of wood pellets or other residues. Some Brazilian standards adopted for briquettes and charcoal, and these are adapted for the 
characterization of pellets. Given this gap, European and American standards are used for reference values. Standardization is used to guarantee the quality required by the customer, always aiming at continuous improvement. Usual standards in the market of pellets are: (SS187120), (ONORM M7135), (DIN 51731) and the recommendations of the Pellets Fuel Institute.

To the best of the authors' knowledge, there are no studies that perform an evaluation of wood pellets under the Brazilian context in a way to point which shows the best energy performance, based on their physical, chemical and thermal characteristics. Thus, this paper is aimed at analyzing and comparing a set of pellets of different compositions, based on their physical, chemical and thermal characteristics for energy purposes, comparing them against international standards.

The increasing demand for energy brings about the increase in the need to seek clean and renewable energy, aiming to minimize environmental impacts. Energy generation from waste is an economically and environmentally sustainable alternative, once it contributes to minimizing the negative impacts caused by mismanagement of waste and also adds value to waste, being an input to a "new" product, closing a cycle.

This piece of research presents a way to assist companies in the process of developing sustainable wood products, obtaining increased valorization of agroindustrial and wood byproducts by generating energy and reducing the dependence on fossil fuels, such as charcoal, oil and natural gas. It also contributes to the body of literature on biomass for energy generation.

Given the initial considerations about the study, the motivation for developing this piece of research and the aim of this paper presented in this initial section, section 2 describes the materials and methods used to conduct the research, whereas section 3 presents and discusses the results and section 4 draws on the conclusions and suggestions for further research. 


\section{Material and methods}

\subsection{Material}

In this study, three types of pellets from different compositions were analyzed, designated as P1 - pellets consisting of Pinus ssp. with 15\% (in mass) of charcoal fines, P2 pellets produced from Pinus ssp. and; P3 - pellets produced from Eucalyptus ssp. shaves. The samples (P1, P2 and P3) are shown in Figure 1a, 1b and 1c, respectively.

Figure 1 - Samples of the Pellets analyzed

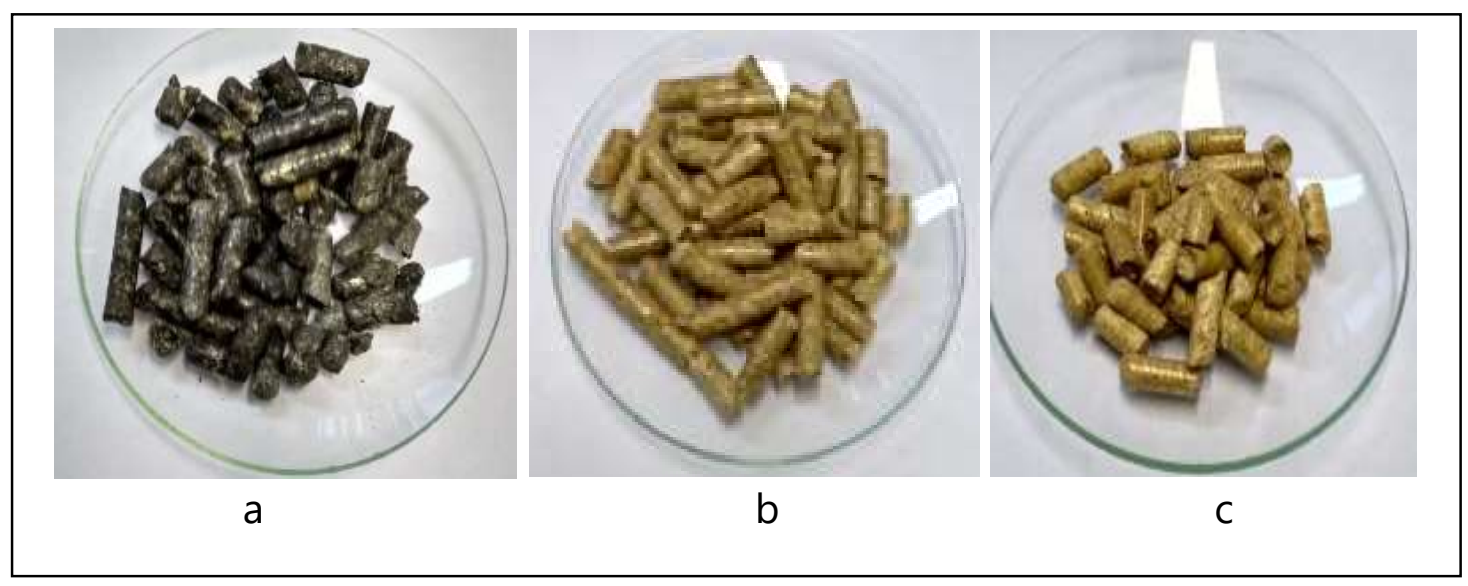

Source: Authors (2019).

\subsection{Characterization of pellets}

The pellets were characterized according to their physical properties (dimensions, bulk density and mechanical durability), chemical (immediate analysis - moisture content, ash, fixed carbon and volatile materials) and energy (energy density and higher and lower heating values) according to the standards listed in Table 1. For all analyses, 3 replicates were performed, using the mean value among them for each sample.

Table 1- Parameters used and their respective standards.

\begin{tabular}{rc}
\hline Parameter & Standard \\
\hline Moisture content (MC) & ABNT NBR 14929/2003 \\
\hline
\end{tabular}




\begin{tabular}{ll}
\hline Immediate analysis & ABNT NBR 8112/1983 \\
\hline Higher Heating Value (HHV) & ABNT NBR 8633/1984 \\
\hline Bulk Density (BD) & ABNT NBR 6922/1981 \\
\hline Dimensions of pellets & ONORM M 7135/2000 \\
\hline Mechanical durability (Du) & CEN/TS 15210-1/2005 \\
\hline
\end{tabular}

There is no specific standard to characterize pellets in Brazil, hence, charcoal standards were adapted to analyze and characterize these sources of biofuel. However, some tests were conducted based on American and European pellet classification standards, such as the European Committee for Standardization (CEN), in order to adopt high quality parameters.

\subsection{Gas analysis of pellet combustion}

For this analysis, a portable electrochemical analyzer, model UNIGAS 3000 MK III, manufactured by EUROTRON, was used to verify the gaseous emissions and determine the chemical composition of the combustion gases. The composition of the gases (CO, NOX and SO2) was determined in this analysis. In order to perform this analysis, the gas analyzer was introduced in a duct in the boiler stack (where the highest concentration of gases is located) during the combustion of each material (P1, P2 and P3). During the analysis, time, mass and gas flow were controlled.

\subsection{Statistical analysis}

An analysis of variance was performed at a $5 \%$ probability level; and the Tukey test for comparing means of the treatments, was performed at the level of $5 \%$ of probability. For the comparison between means in the Tukey test, it was made use of letters $(a, b, c)$ : means accompanied by the same letter did not differ statistically among themselves, at the level of $5 \%$ of probability. The analyses were performed in the RGui statistics software tool.

Research manuscripts reporting large datasets that are deposited in a publicly available database should specify where the data have been deposited and provide the relevant accession numbers. If the accession numbers have not yet been obtained at the 
time of submission, please state that they will be provided during review. They must be provided prior to publication.

According to Wu et al (2011), the pellets have a moisture content of approximately $8 \%$ and a bulk density of more than $600 \mathrm{~kg} / \mathrm{m}^{3}$. Lower values of bulk density result in higher transportation costs, which affect the storage capacity of producers and consumers.

From the data shown in Table 2, it is possible to analyze that there is a relationship between the moisture content of each sample and its mechanical durability. The P3 pellets presented a lower moisture content in comparison to the others, resulting in greater mechanical durability of $98.83 \%$, and the P2 pellets, which obtained the highest moisture content, confirmed this relation, since its durability was the lowest $95.91 \%$.

CEN/TS 15210-1, reports that wood pellets must have mechanical durability above 95\%. It can be observed that all pellets meet this requirement according to this standard, since the respective values of $\mathrm{P} 1, \mathrm{P} 2$ and $\mathrm{P} 3$ were $96.73 \%, 95.91 \%$ and $98.83 \%$.

Interventionary studies involving animals or humans, and other studies require ethical approval must list the authority that provided approval and the corresponding ethical approval code.

\section{Results and discussion}

\subsection{Characterization of pellets}

The results with respect to the physical characteristics of the pellets are presented in Table 2. The Austrian standard ONORM M7135 was adopted as reference, since among the usual international standards it is the one of greater rigor regarding the characteristics analyzed.

Table 2 - Physical properties of pellets.

Physical

Properties
Unit

P1
P2
ONORM

M7135 


\begin{tabular}{lccccc}
\hline Average Diameter & Mm & $6.67^{a}$ & $6.67 a$ & $6.66 a$ & 4 a 10 \\
\hline Medium Length & Mm & 14.41 & 11.23 & 16.15 & 11.5 a 22.1 \\
\hline Maximum Length & Mm & 26.06 & 20.86 & 35.12 & 19.2 a 34.4 \\
\hline Minimum Length & Mm & 5.55 & 6.74 & 6.41 & 6.6 a 13.2 \\
\hline Pellets/ 100g & Unit & $232^{a}$ & $398 b$ & $273 c$ & 198 a 545 \\
\hline Bulk Density & Kg.m-3 & $660.6^{a}$ & $645.6 b$ & $675.0 c$ & $>600$ \\
\hline Mechanical & $\%$ & $96.73^{a}$ & $95.91 b$ & $98.83 c$ & $>95$ \\
Durability & & & & \\
\hline
\end{tabular}

\subsection{Immediate analysis of pellets}

The results of the immediate pellet analysis are presented in Table 3.

Table 3 - Immediate chemical analysis of pellets.

\begin{tabular}{lcccc}
\hline \multicolumn{1}{c}{ Parameter } & P1 & P2 & P3 & Literature \\
\hline Fixed carbon, \% & $22.30 a^{*}$ & $18.03 \mathrm{~b}$ & $13.74 \mathrm{c}$ & 14.56 a 15.63 \\
\hline Volatile materials, \% & $76.62 \mathrm{a}$ & $80.86 \mathrm{~b}$ & $85.27 \mathrm{c}$ & 83.4 a 84.9 \\
\hline Ash content, \% & $1.08 \mathrm{a}$ & $1.11 \mathrm{a}$ & $0.99 \mathrm{a}$ & $<0.6$ \\
\hline Moisture content, \% & $9.02 \mathrm{a}$ & $12.36 \mathrm{~b}$ & $4.95 \mathrm{c}$ & $<12$ \\
\hline
\end{tabular}

*Means followed by the same letters do not show statistical difference (Tukey, $\alpha=0.05$ ).

According to Artemio et al., (2018), wood pellets have values of 72.25 to $80 \%$ for volatile material contents, 15 to $21 \%$ for fixed carbon content and 2.41 to $3.22 \%$ for ash content. Thus, it can be observed that, in general, the pellets presented high values of volatile content, ranging from $76.62 \%$ for pellets $\mathrm{P} 1$ to $85.27 \%$ for $\mathrm{P} 3$. In relation to fixed carbon, $\mathrm{P} 1$ pellets presented higher values than the ones observed in the literature, this improvement may be the result of the addition of charcoal fines. Sources with high fixed carbon content allow slowing down the burning process; and high levels of volatile materials increase the point of ignition during the combustion of pellets. Moreover, compared to the pellets produced by Artemio et al., (2018), in relation to the ash content, the pellets P1, P2 and P3 stood out as 
all of them presented values lower than $1.11 \%$ in relation to this quality parameter. Values higher than $3 \%$ of ash content can cause corrosion problems and incrustations to the boilers and burners, so the pellets analyzed showed values that would minimize these problems.

\subsection{Energy characterization of pellets}

The bulk density is of great importance to quantify the volume of materials that have irregular geometries, since it provides useful information to the logistics sector, considering the empty spaces between the particles during transportation of these materials. Moreover, the bulk density (BD) is important for obtaining the energy density (ED) of the pellets. The results concerning energy characterization are presented in Table 4.

Table 4 - Energy values of pellets.

\begin{tabular}{lccccc}
\hline \multicolumn{1}{c}{ Properties } & Unit & P1 & P2 & P3 & Literature \\
\hline HHV & MJ kg-1 & $20.52^{\mathrm{a}}$ & $20.25 \mathrm{~b}$ & $20.16 \mathrm{c}$ & - \\
\hline LHV 0\% & MJ kg-1 & $19.16^{\mathrm{a}}$ & $18.89 \mathrm{~b}$ & $18.80 \mathrm{c}$ & $>18$ \\
\hline MJ kg-1 & & & & $18.71-$ \\
HHV MC\% & & $18.67^{\mathrm{a}}$ & $17.75 \mathrm{~b}$ & $19.16 \mathrm{c}$ & 19.48 \\
\hline UHV & MJ kg-1 & & & & $17.29-$ \\
\hline BD & & $17.32^{\mathrm{a}}$ & $16.39 \mathrm{~b}$ & $17.8 \mathrm{c}$ & 18.13 \\
\hline MC & $\mathrm{kg} \mathrm{m-3}$ & $660.64^{\mathrm{a}}$ & $645.58 \mathrm{~b}$ & $675.1 \mathrm{c}$ & $638.0-$ \\
\hline ED & & & & 647.4 \\
\hline
\end{tabular}

HHV - higher heat power; LHV - lower heat power; UHV - useful heat power.

The highest HHV values obtained were for P1 pellets with $20.52 \mathrm{MJ} . \mathrm{kg}-1$, while the highest value for HHVTU\% was for P3 pellets with $19.16 \mathrm{MJ} \mathrm{kg-1.} \mathrm{A} \mathrm{factor} \mathrm{that} \mathrm{may} \mathrm{have}$ impacted this quality parameter for P1 pellets is that it had been added $15 \%$ of charcoal fines to them, which caused the material to present higher HHV and LHV. 
Furthermore, according to Ferreira et al. (2014), the moisture content can affect the heating value of the pellets. By multiplying the calculated value of the LHV by the bulk density, the energy density of the pellets is obtained. In this case, the P3 pellets presented the highest value, being it 12.02 GJ.m-3.

It is possible through Figure 2 to verify and differentiate the main quality parameters analyzed during the characterization of the pellets.

Figure 2 - Quality parameters between pellets produced

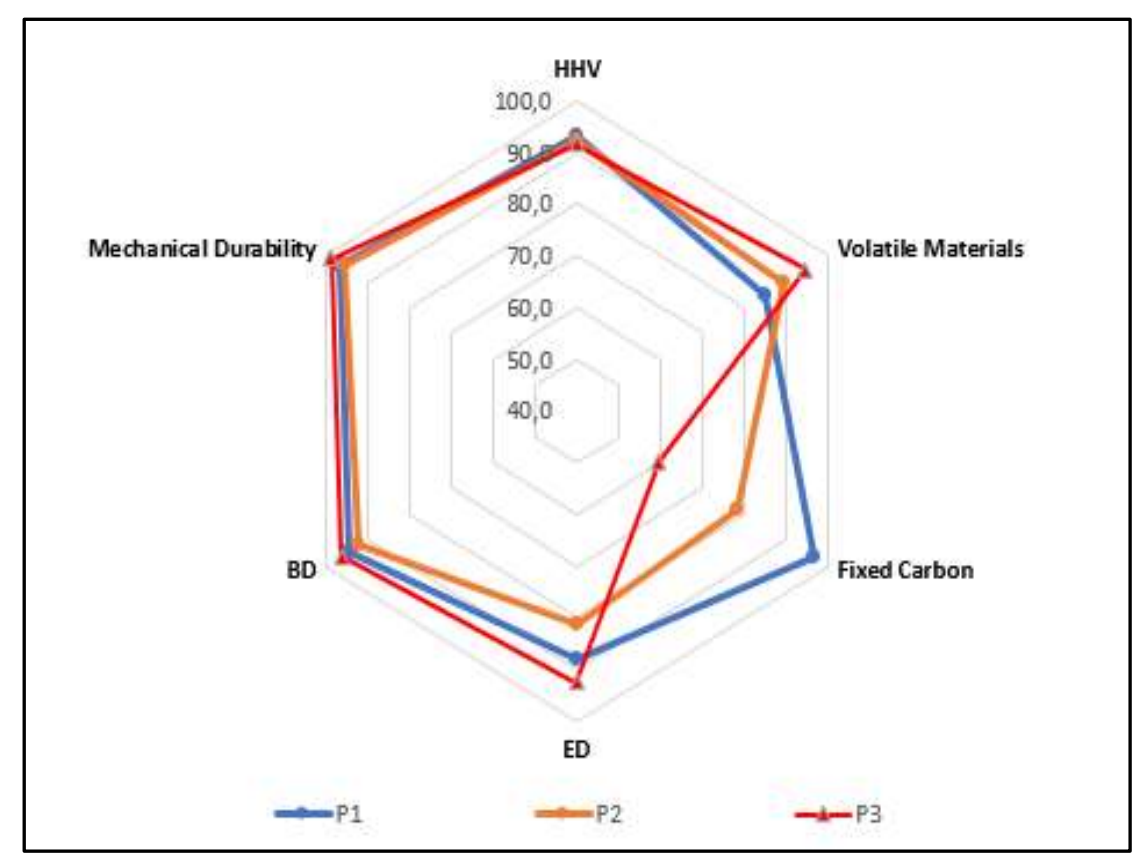

Source: Authors (2019).

P1 and P3 pellets stand out in almost all quality parameters. The P1 pellets did not stand out in relation to the fixed carbon content, however, they obtained values greater than or equal to P2 and P3 in the other analyzed items.

\subsection{Analysis of gaseous emissions in the combustion of pellets}

It was possible to observe that in relation to NOX emissions, all the pellet samples analyzed were below the maximum values stipulated by the CONAMA (2018) standard, which is $80 \mathrm{mg}$. N-1.m-3. Furthermore, emissions of $\mathrm{CO}$ during combustion were higher than the stipulated by the standard, 7800 mg.N-1.m-3. Figures 3 and 4 present the $\mathrm{CO}$ and NOX emission values, respectively, for the pellets analyzed. 
Figure 3 - CO emissions during pellet combustion

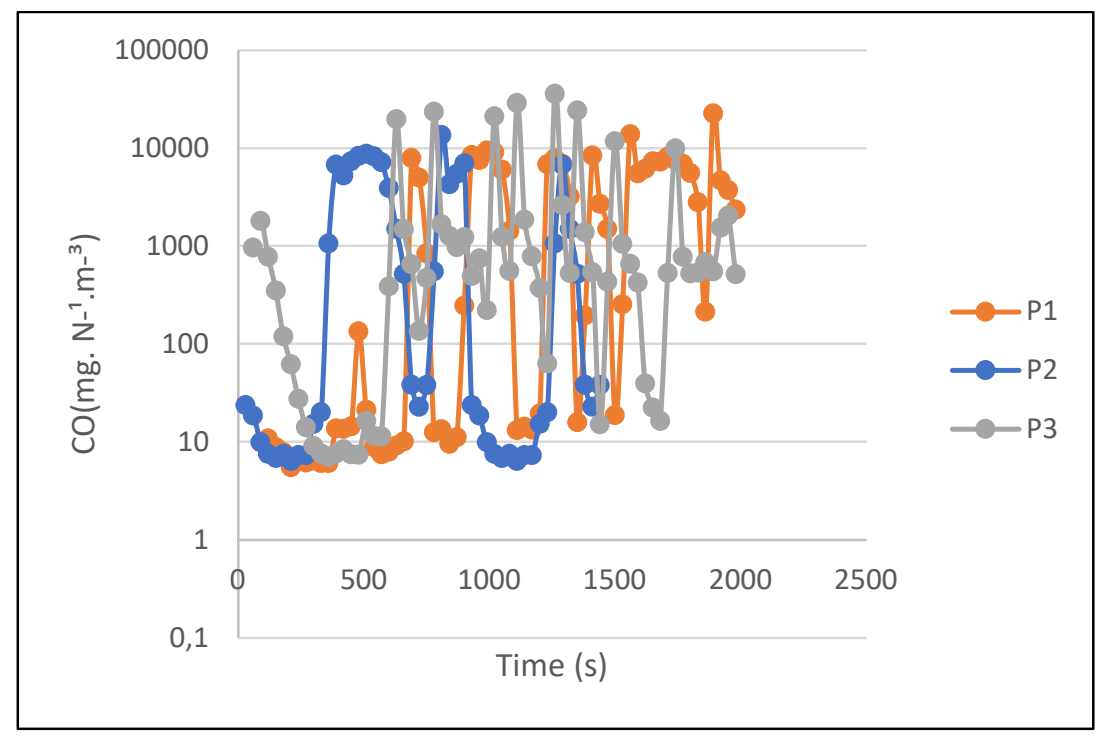

Source: Authors (2019).

It can be seen from Figure 3 that $\mathrm{P} 1$ pellets emitted values with higher $\mathrm{CO}$ peaks, this is a value that was expected due to the addition of charcoal fines to P1 pellets. P3 pellets had lower $\mathrm{CO}$ values when compared to P1 and P2 pellets. This value may be associated with a lower amount of fixed carbon and ash present in P1 pellets. The peaks presented may be related to the timing of pellet feed in the boiler (manual feed), as initially there is a reduction in carbon monoxide and increase in gaseous oxygen (O2) measured by the gas analyzer when a new feed is performed. These values increase rapidly and eventually stabilize.

Figure 4 - NOX emissions during pellet combustion

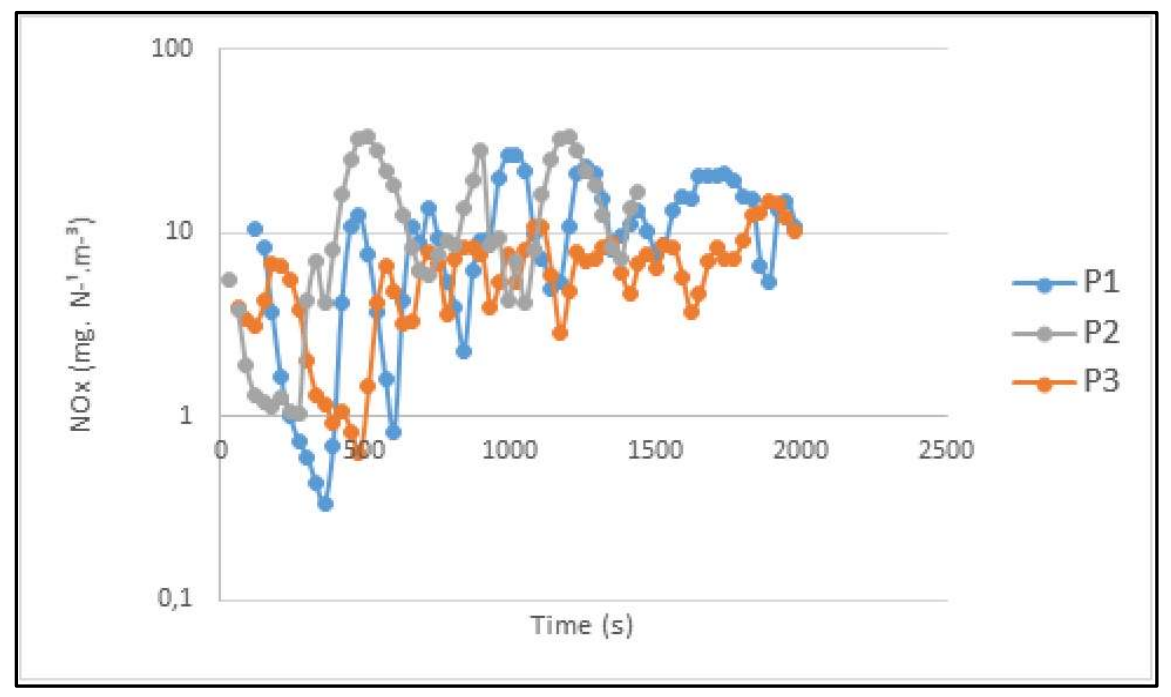

Source: Authors (2019). 
For NOx emissions, none of the pellet samples exceeded the maximum values allowed by the CONAMA standard, these can be observed from Figure 4. All samples analyzed presented low levels of nitrogen oxides. According to Garcia; Caraschi; Ventorim (2017), the addition of wood bark during the pellet production process may be a factor in increasing the amount of NOx emitted during pellet combustion. In the pellets analyzed there was no addition of peels.

\section{Conclusions}

From the results it was concluded that considering the moisture content, mechanical durability and LHV, all the pellets achieved the quality parameters required by the international standards.

Pellets can contribute significantly to minimizing potential environmental and financial impacts compared to charcoal and oil. The available amount of material for pellet production also encourages its use and, as the sources for pellet production are characterized as renewable, it increases the potential for future investments in pellets from wood or lignocellulosic materials.

Opportunities for future work comprise including economic (seeking low raw material and labor costs), environmental (assessing related environmental impacts) and social (minimizing possible social impacts) parameters in the assessment of different pellets, and developing new products with energy potential.

Due to the current concern with the scarcity of energy sources, the use of wood pellets (due to their energy potential) contributes financially to the population, industries, institutions and consumers in general, since the values referring to energy sources tend to increase as they become more scarce. This section is not mandatory, but can be added to the manuscript if the discussion is unusually long or complex.

(Continue...) 


\section{Funding}

This research was funded by the Coordination of Improvement of Higher Education Personnel (CAPES) and the National Council for Scientific and Technological Development (CNPq).

\section{References}

ARRANZ, J. I. et al. Characterization and combustion behaviour of commercial and experimental wood pellets in South West Europe. Fuel, v. 142, p. 199-207, 2015.

ARTEMIO, Carrillo Parra et al. Physical, mechanical and energy characterization of wood pellets obtained from three common tropical species. PeerJ, v. 6, p. e5504, 2018.

ASSOCIAÇÃO BRASILEIRA DE NORMAS TÉCNICAS - ABNT. NBR 14929. Madeira Determinação do teor de umidade de cavacos - Método por secagem em estufa. Rio de Janeiro, 2003.

ASSOCIAÇÃO BRASILEIRA DE NORMAS TÉCNICAS - ABNT. NBR 8112/86. Carvão vegetal Análise Imediata. Rio de Janeiro, 1986.

ASSOCIAÇÃO BRASILEIRA DE NORMAS TÉCNICAS - ABNT. NBR 8633/84. Carvão vegetal Determinação do poder calorífico. Rio de Janeiro, 1984.

ASSOCIAÇÃO BRASILEIRA DE NORMAS TÉCNICAS - ABNT. NBR 6922. Carvão vegetal Ensaios físicos - Determinação da massa específica - Densidade a granel. Rio de Janeiro, 1981.

DENG, Tong; ALZAHRANI, Abdullah M.; BRADLEY, Michael S. Influences of environmental humidity on physical properties and attrition of wood pellets. Fuel processing technology, v. 185, p. 126-138, 2019.

DEUTSCHES INSTITUT FUR NORMUNG (DIN). Testing of solid fuels. Compressed untreated wood. Requirements and testing. 1996.

FAOSTAT, Food. Agriculture Organization of the United Nations Database. The agricultural production. Available at:< http://www. apps. fao. org >. Acessed on Jun, v. 20, 2017.

FERREIRA, P.T., FERREIRA, E. M.; TEIXEIRA, J.C. FERREIRA, Pedro T.; FERREIRA, Manuel E.; TEIXEIRA, José $C$. Analysis of industrial waste in wood pellets and co-combustion products. Waste and Biomass Valorization, v. 5, n. 4, p. 637-650, 2014. 
FINNISH STANDARDS ASSOCIATION et al. CEN/TS 15210-1: 2005 "Solid biofuels. Methods for the determination of mechanical durability of pellets and briquettes. Part, v. 1, 2006.

GARCIA, Dorival Pinheiro; CARASCHI, José Cláudio; VENTORIM, Gustavo. Emissões de gases do efeito estufa da queima de pellets de madeira. Floresta, v. 47, n. 3, 2017.

JIANG, Zehui et al. Effects of carbonization conditions on properties of bamboo pellets. Renewable energy, v. 51, p. 1-6, 2013.

LEHMANN, Bastian et al. Effect of miscanthus addition and different grinding processes on the quality of wood pellets. Biomass and bioenergy, v. 44, p. 150-159, 2012.

MANI, Sudhagar et al. Economics of producing fuel pellets from biomass. Applied Engineering in agriculture, v. 22, n. 3, p. 421-426, 2006.

NATIONAL COUNCIL OF THE ENVIRONMENT - CONAMA. Gas emissions, resolution no. 490, of November 16, 2018.

NORMUNGSINSTITUT, Österreichisches. ÖNORM M 7135: compressed wood or compressed bark in natural state: pellets and briquettes: requirements and test specifications. Vienna, Austria, 2000.

PELLET FUEL INSTITUTE, Pellet Fuels Institute Standard Specification For Residential/Commercial Densified Fuel, Pellet Fuel Institute, Arlington, Va, USA, 2010.

SIKKEMA, Richard et al. The European wood pellet markets: current status and prospects for 2020. Biofuels, Bioproducts and Biorefining, v. 5, n. 3, p. 250-278, 2011.

SOLID BIOFUELS -- Determination of mechanical durability of pellets and briquettes - Part 1: Pellets. ISO 17831-2:2015.

SWEDISH STANDARDS. SS 187180: Biofuels and Peat - Determination of mechanical durability of pellets and briquettes, pellets. Classification Swedish Standards. Stockholm, 1999.

TOSCANO, G. et al. Investigation on wood pellet quality and relationship between ash content and the most important chemical elements. Biomass and bioenergy, v. 56, p. $317-$ 322, 2013.

WU, M. R.; SCHOTT, D. L.; LODEWIJKS, G. Physical properties of solid biomass. Biomass and bioenergy, v. 35, n. 5, p. 2093-2105, 2011.

ZOU, Caineng et al. Energy revolution: From a fossil energy era to a new energy era. Natural Gas Industry B, v. 3, n. 1, p. 1-11, 2016. 